\title{
CANCIONES PROFANAS
}

No es sencillo saber en dónde y cuándo se inicia un acto creativo, ni si el mismo procede de una exigencia espiritual o de la magia, si ha sido dictado por un mandato imperioso del cosmos o si estaba escrito de antemano en nuestros genes. Crear es una fuerza arrolladora e indefinible y narrar, una de sus vertientes, tan atractiva como diseñar un laberinto, inventar un jeroglífico, buscar galeones hundidos en el fondo del océano, escalar montañas prohibidas, descifrar los signos de un idioma antiquísimo que, a fuerza de voluntad, cada escritor intenta transformar en nuevo y futurista.

El narrador, desde mi perspectiva, escribe en cuatro, seis y nueve y más escalas al mismo tiempo. Lo heredado, lo aprendido, lo imitado, lo soñado, lo impuesto, lo compartido y todo aquello que sale al paso desde lo cotidiano, la intuición, el asombro, la maravilla, el horror, el júbilo y la muerte.

No hay nada más fascinante que planear un relato, cavar sus invisibles cimientos, viajar a través de esa nada del papel en blanco, otorgar forma a lo que existe o no existirá jamás. Es más increíble todavía transitar por el esqueleto de una his toria ya escrita, reintentar de nuevo los pasos que llevaron a cada palabra, frase y acción.

A escribir se roban las frases al amigo y al transeúnte, se plasman rasgos de tres personas en un rostro, se ama y se odia más de una vez a lo largo de un día de trabajo. Pero, lo que más sorprende y desconcierta son las razones del cerebro; él tiene sus propias metas, puntos de vista, procesos de corrección, tiempo exacto para cada frase, narración y libro; tiene además la extraña capacidad de aglutinar en un párrafo el tema que se insinuaba como saga familiar o extender a través de una novela la audacia, la belleza o la frivolidad, el mal y el bien, todas las virtudes o pecados, creándoles vidas yentornos.

Cuando ipor fin! se tiene la certeza de un acierto, tampoco se ha conquistado la plena satisfacción y menos el reposo. A veces surge un creador errático, viajero en las neuronas, quien en duemevela decide ampliar lo escrito, o abrir compuertas que han estado cegadas - unas conducen a la infancia, otras al porvenir, y las demás al reino de lo insólito, surtidores o claraboyas, explosiones, terremotos.

Cerebro y subconsciente se ríen de los narradores. Actúan como esos magos de los cuentos para niños. Sí, te permiten entrar al universo de la literatura, viajar por sus reinos, cargar un bagaje de tesoros, mientras a lo largo del camino surgen el peligro y las alimañas, brotan las palabras festivas, lecturas y escritores agazapados en la memoria, trampas y riscos, los dragones de la locura y los abismos del desasosiego.

${ }^{*}$ Escritora 
Sin embargo, en ocasiones, al escribir-cada texto se presume como el mejor, el único, el último y el primero-he sentido que perdía la conexión con la realidad de la irrealidad literaria y me sentía flotar por encima del cuaderno, la máquina de escribir o la pantalla del computador. El tema imaginado y la emoción para forjar su propia esencia se me escapaban de la mente, como si eligiera atmósfera, clima, colores, aromas, límites, situaciones trágicas o risibles. Ciertos temas y personajes están dispuestos también a entrometerse, no les im porta fallar, quieren existir a toda costa. De repente, no soy yo quien decide, sino un reflejo que ha alimentado otro "yo" con menos prejuicios y muletas, que desea más aire, espacios ilimitados, jarana, aguaceros, crueldad. Esa historia, que tanto esfuerzo había cos tado narrar, se refunde en sí misma y termina convertida en otra, sin que tal metamorfosis implique la desaparición total de la primera. Ella ha dividido su médula, cedido territorio, mientras se reconstruye, traza planos, desecha y elige materiales, finge haber sucumbido a la avalancha del tema advenedizo fortalecido en la clandestinidad. En realidad ha enfocado una dirección opuesta y tomado nuevos ropajes, está lista a resurgir; es difícil que muera. Además, están las historias imaginadas y escuchadas día a día, como si se transitara bajo una lluvia de ideas e información. Se insinúan mientras hablas y caminas, flotan como arena o polen mecido por la brisa, te apartan de la televisión y la internet, titilan al tropezar con desconocidos y al escuchar una melodía; son frases, en apariencia insustanciales, que luego formarán el antes y el después de mis narraciones: las escritas y las que esperan turno, las asaltantes y las rezagadas.

¿Cómo y cuándo se inicia un proceso creativo? ¿Un cuento? ¿Cómo persiste el hilo conductor? Unas cuantas veces en mi vida lo he sabido, en el lugar y el momento exactos, aunque tal fortuna en general resulta esquiva.

Una vez, en una casa junto al mar, entre isleños que jugaban a las cartas y mujeres que hablaban con malicia de sus vecinos, escucho una voz masculina con acento inglés que, iracunda, domina las conversaciones y dice: "El que juega lo hace para ganar... aunque acepte con entereza la derrota". "Pero nunca tuviste el coraje de ser un perdedor..." le responde mi mente que, en ese instante inicia un relato.

Una tarde, almorzaba con un amigo en uno de esos sitios que llaman típicos, con manteles a cuadros y camareros que ejercían el orgullo del no-trabajo. En la mesa de al lado, un hombre enome y de cabellos negros-de espaldas a míhablaba quedo, helado y cruel, mientras su compañera lloraba y lloraba, sin ningún pudor, el rostro hinchado por el dolor y la desesperanza. Un enano de camis a roja y pantalones azul turquí, que vendía

rosas, se le acercó. Él sacó la billetera y compró una docena, displicente. Al ladear la cabeza, vislumbré una nariz de águila, labios estrechos que intentaron sonreír. El enano me miró con una chispa de piedad en sus ojos claros y se alejó con pasos cortos, temblorosos. Sabía que su venta correspondía a la muerte del amor y quizá no deseaba tentar a la suerte. 
Años más tarde, estoy junto a una piscina, absorta en un libro de ciencia ficción, a pesar del calor, los mosquitos y las homigas, la resolana, los juegos de varios niños en el agua y sus madres que exclaman... "¡Cuidado...! no seas brusco, no salpiques". De repente, se extiende por el jardín un instante de silencio. Escucho la voz de una mujer rubia, que dice, eufórica: "Vengo de lo profundo del mar, soy de la Atlántida. Me lo ha dicho el maestro Sri Bey, la reencarnación de Aurobindo". Y cuando dijo "Aurobindo" supe que lograría redondear una novela corta: en otra pis cina, sin la chiquillería, mientras dos hombres tomarán whisky ya causa de una apuesta destruirán el matrimonio de una pareja muy joven en su luna de miel. No, no, hoy no, le insistí a mi tercer yo o a su reflejo, a ese que desea narrar en todo momento y a toda costa. Quiero un respiro, ayer concluí un relato, necesito un poco de ocio, ahora estoy leyendo... Mientras tanto, la brisa dispersó las palabras de la mujeres y la algarabía de los niños. Disfruté la lectura; ni por asomo recordaba una historia de amor ya escrita-el amor entre un niño autista y una iguana todavía con un pasaje endeble que no me permitía darla por terminada, cuando decidí retornar al apartamento. Llevaba la silla de plástico al hombro, toalla, libro, sol, cuando, frente al edificio me sale al paso una iguana, de un color verde-hoja-brillante y cola listada, que se planta con insolencia al paso, como si me dijera: “iMírame! ¡ Soy así, estoy dispuesta a participar en tu narración, equilibrar el párrafo que te molesta!". En ese momento suena el timbre de la puerta del conjunto residencial. Entra un muchacho de traje blanco y ojos aceitunados, dice hola, se detiene junto a la iguana, y bajo el resplandor: "Por favor, váyase o ella no se moverá. Se cree escondida en la manigua". Camino hasta las escaleras del edificio y veo cómo la lguana sube por la pierna del muchacho, salta primero a su hombro y luego trepa a una palmera. "Chao, mi verde", le dice. Después sonríe y sus ojos de aceituna chispean. "Ella y yo somos íntimos amigos des de mi infancia."

Tantas y tantas historias, desde personajes y mundos paralelos, que imagino en espiral, decaedros y octaedros, que me hablan del mar, otros del frenesí, el delirio o la violencia, del pánico y la risa, que me permiten incursionar en el imperio de las ideas, la reflexión y quizá los desaciertos, vivir la aventura de escribir. Esta aventura me permite ejercer la telepatía, la lectura de voces y gestos, colonizar galaxias, practicar sortilegios y exorcismos, vis lumbrar otras dimensiones, armar y desarmar castillos en la marea, jugar a la ciencia, revivir costumbres paganas, hasta domitar en el aire entre el sonido y la fragilidad de una canción.

Cuando se es cribe no se piensa en el presente, ni en el amor, ni el dolor, ni en la efímera inmortalidad del intelecto, ni en lectores desvelados o iracundos, ni en las secuelas del fracaso o del éxito. Se vive una vida de célula multiplicándose, no se es quien se es, ni quien tú crees ser o los demás dicen que eres, sino alguien que explora uno de los innumerables senderos que cruzan el reino de la literatura y la fantasía con, sin embargo, la mirada y el anhelo colocados en las grandes autopistas centrales, los fabulosos viajes del mañana a través de la imaginación y la palabra. 